\title{
Adenoidal tissue expression of CD23 (FcERII): An evaluation with reference to recurrent upper respiratory tract complaints and allergy in children
}

\author{
Adenoid doku CD23 (FcERII) ekspresyonu: Çocuklarda tekrarlayan üst solunum yolu \\ enfeksiyonu yakınmaları ve allerji temelinde bir değerlendirme
}

\author{
Demet Alaygut ${ }^{1}$, Mehtat Ünlü${ }^{2}$, Semih Sutay ${ }^{3}$, Özkan Karaman ${ }^{4}$, Özden Anal ${ }^{5}$
}

\begin{abstract}
Objective: In this study, CD23, low affinity immunoglobulin $\mathrm{E}$ receptor, expression in the adenoid tissue was investigated immunohistochemically and evaluated with regard to upper respiratory tract infection complaints and allergy.

Methods: This retrospective study was performed by the selection of 100 patients aged 2-13 years who underwent adenoidectomy/adenotonsillectomy and in whom the adenoid tissue pathological studies were reported as "lymphoid hyperplasia and chronic infection" were evaluated. Immunohistochemical evaluation of CD23 expression was scored semiquantitatively between $0-3$ in the tissue samples.
\end{abstract}

Results: The mean age in the study group was 70.7 months; $46 \%$ were female; $30 \%$ of patients had adenoidectomy only. Following the operation, the infection frequency decreased in $91 \%$ of patients, whereas allergy symptoms were unchanged in $84 \%$. CD23 expression was found significantly lower in patients who had allergic manifestations, namely urticaria $(p=0.041)$, drug sensitivity $(p=0.035)$ and pollen allergy $(p=0.037)$.

Conclusion: A significantly reduced CD23 expression was found in adenoidal tissue in patients with allergic symptoms. These results can be assessed as an underlying mechanism for the recurrence of respiratory tract complaints in these children, despite adenoidectomy. $J$ Clin Exp Invest 2013; 4 (1): 1-7

Key words: CD23 expression, adenoid tissue, atopy

\section{ÖZET}

Amaç: Bu çalışmada, CD23, IgE'nin düşük afiniteli reseptörü immunohistokimyasal yöntemle değerlendirildi ve üst solunum yolu enfeksiyonu ve alerji semptomlarının varlığına göre analiz edildi.

Yöntemler: Bu retrospektif çalışmaya yaşları 2-13 yaş arasında değişen adenoidekromi ve adenoidektomi/ tonsillektomi operasyonu geçiren 100 hasta alındı. Patoloji raporları lenfoid hiperplazi ve kronik enfeksiyon şeklinde olanlar çalışmaya dahil edildi. Immunohistokimyasal olarak CD23 ekspresyonu semikantitatif metodla (0-3) arasında değerlendirildi.

Bulgular: Çalışma grubunun ortalama yaşı 70,7 ay, \% 46 'sı kız hastalardan oluşmaktaydı ve hastaların \% 30'u sadece adenoidektomi operasyonu geçirmişti. Operasyon sonrası, enfeksiyon sıklığı \% 91 oranında azalmakla birlikte, alerji semptomları \%84 oranında değişmemişti. CD23 ekspresyonu özellikle ürtiker yakınması olanlarda $(p=0,037)$, ilaç alerjisi olanlarda $(p=0.035)$ ve polen alerjisi $(p=0.041)$ olanlarda anlamlı olarak düşük bulundu.

Sonuç: Atopik hastalarda adenoid dokuda CD23 yüzey ekspresyonunun azalacağı tezini destekler şekilde ürtiker, ilaç allerjisi ve polen allerjisi olan hastalarda CD23 yoğunluğunu anlamlı olarak azalmış saptandı. Bu sonuçlar, adenoidektomiye rağmen tekrarlayan solunum yolu semptomları olan çocuklarda altta yatan mekanizmayı açıklamak açısından değerlendirilebilir.

Anahtar kelimeler: CD23 ekspresyonu, adenoid doku, atopi

${ }^{1}$ Dokuz Eylül University Faculty of Medicine, Department of Pediatrics, Izmir, Turkey

${ }^{2}$ Dokuz Eylül University Faculty of Medicine, Department of Pathology, Izmir, Turkey

${ }^{3}$ Dokuz Eylül University Faculty of Medicine, Department of Otorhinolaryngology, Izmir, Turkey

${ }^{4}$ Dokuz Eylül University Faculty of Medicine, Department of Pediatric Allergy, Izmir, Turkey

${ }^{5}$ Dokuz Eylül University Faculty of Medicine, Department of Pediatric Immunology, Izmir, Turkey

Correspondence: Demet Alaygut,

Dokuz Eylül University Hospital, Department of Pediatrics, İzmir, Turkey Email: demetalaygut@yahoo.com

Received: 05.02.2013, Accepted: 18.02.2013

Copyright (C) JCEI / Journal of Clinical and Experimental Investigations 2013, All rights reserved 


\section{INTRODUCTION}

Respiratory tract complaints that involve the adenotonsillar tissues are one of the most frequently encountered health problems in childhood. Adenoidectomy and/or tonsillectomy is a common treatment procedure after the preschool age. The adenoids and tonsils constitute the first local immune defense especially at exposure to inhaled allergens. Recurrent rhinitis, rhinosinusitis, otitis, laryngeal irritation from post-nasal drip and chronic cough secondary to this condition are causes of significant morbidity for both children and their families. ${ }^{1}$ In the wake of an exposure to an allergen, hypertrophy ensues in the adenotonsillar tissue at the gate of the respiratory tract compromising the airway in the child. Thus, adenotonsillectomy is the choice of treatment in many cases.

$\operatorname{lgE}$ antibody, which plays an essential role in all allergic conditions, binds to high-affinity IgE receptors (FcERI) on the surface of mast cells and basophils. CD23 (FceRII) is the low-affinity receptor for $\operatorname{lgE}$. Although it is found mainly on the surface of $B$ lymphocytes, it is also found on that of many other cells and it is expressed by a majority of hematopoietic cells such as B cells, eosinophils, platelets and monocytes. ${ }^{6}$ In humans, as differently from other Fc receptors, (FceRII) is not a member of the immunoglobulin family; it is in the form of a $\mathrm{Ca}+2$ dependent C-lectin as a Type II transmembrane glycoprotein which shows complete homology with mannose binding protein. ${ }^{7}$ In the present study, the aim was to study CD23 expression in the adenoid tissue from a immunohistochemical viewpoint and evaluate them with reference to frequently recurring upper respiratory tract complaints.

\section{METHODS}

The study was conducted retrospectively on patients between the ages 2-13 who were treated with adenoidectomy or adeno-tonsillectomy in the Dokuz Eylül University Medical Faculty Hospital by the Otolaryngology Department. The surgical data covering the period were obtained from the records of the Department of Pathology. The said pathology reports covered a total of 168 patients. Particular care was taken that the reports had been classified as related to lymphoid hyperplasia and chronic infection cases. To double-check on the patient age and date of surgery data, these were compared with those in the patients' files in the hospital archives, and also their telephone numbers were listed for the questionnaire planned. The following were excluded from the study: twelve patients as their files could not be obtained; 5 patients as being outside our age criteria; 2 patients for receiving a diagnosis of actinomyces infection in the pathology report, and 1 patient due to a diagnosis of tuberculosis.

Stored tissue blocks belonging to the remaining 148 patients, minus three, were obtained from the archives of the Pathology Department; and, in effect, 145 patients overall were included in the study. The questionnaire was based on that performed in the "International Study of Asthma and Allergies in Childhood" (ISAAC II) protocol. The patients were contacted and presented with the questions through telephone. We could not establish contact with forty-five patients. A histopathological study on the paraffinized tissue blocks belonging to a total of 100 patients were made by a pathologist who was not informed about the questionnaire or its results.

\section{Definitions of the variants}

The questionnaire designed comprised questions on age at surgery, date of birth, gestational week, breast feeding, number of siblings, attendance to a nursery or kindergarten prior to surgery, duration of nonattendance there, type of surgery (adenoidectomy or adenoidectomy plus tonsillectomy), cause of surgery (frequent infections, obstructive findings and systemic illness). Criteria of frequent infection were based on criteria for tonsillitis, sinusitis and otitis as will be defined below. Sleep apnea, snoring and blockage were interpreted as obstruction findings. Parents were grouped according to asthma as diagnosed by a physician, allergic rhinitis, eczema, presence of urticaria, cigarette smoking by mother (those who smoked during pregnancy, during the child's first year and thereafter were grouped as smokers and the others as non-smokers).

Of the pre-surgical conditions, criterion to be accepted as recurrent was determined as $\geq 3$ times for sinusitis/rhinosinusitis, eight times or more a year for tonsillitis, $\geq 2$ times for bronchiolitis and/or croup, and $\geq 3$ times for frequent otitis media. Questions were directed as to any pre-surgical symptoms such as sneezing; runny, itchy or congested nose; epipharyngeal drip; throat clearing; itchy, watery or red eyes; cough triggered by exercise; or night sweating. Questions pertaining to any antibiotics, antihistaminics, decongestants, steroid-containing nasal sprays, inhaled agents, montelukast, and drugs for immune sytem strengthening that had been used in the pre-surgery period were also included. Questions were asked whether there had been a drop in the frequency and number of the episodes and whether the symptoms still persisted. Other questions were on whether or not a pre-surgical skin 
prick test had been performed, as well as on any allergens that were thought to aggravate the symptoms or demonstrated with skin test (such as pollen, dust, animal hair, cigarette smoke, irritant odors), eczema, allergy to drugs, foods, pollen, animal hair and nose drip, history of urticaria, and presence of angioedema.

\section{Method of data collection}

Data was collected through a pre-designed and tested questionnaire presented via telephone interview technique. We chose this method as this was a retrospective study and many of the families involved lived away and not all addresses could be obtained. We tried to contact the families through their home telephone and mobile for three times in each case, twice on weekdays and once over the weekend and those that could not be contacted were excluded from the study.

\section{Immunohistochemical staining}

Tissue samples, kept in paraffinized blocks in the archives of the Pathology Department of Dokuz Eylül University Medical Faculty, were prepared as $5 \mu \mathrm{m}$ sections on Poly-L-lysine coated slides. Rehydration was effected by keeping the sections in room temperature for a minimum of 24 hours, deparaffinizing them by keeping in xylol for 20 minutes, and passing them through alcohol series of $96 \%$ down to $70 \%$. Boiling (antigen retrieval) was done in $\mathrm{pH}=8$ EDTA buffer for 25 minutes and 20 minutes was allowed for ensuring cooling to room temperature Following this, 3\% hydrogen peroxide was introduced in drops, five minutes was allowed to pass, and then peroxidase activity was blocked and the sections were taken into TRIS solution again. CD23 (Neomarkers) monoclonal antibody, which was prepared in 1:40 dilution without washing, was added in drops to the sections. After being left in room temperature for an hour, they were washed with TRIS, same amount of biotinized secondary antibody was introduced and ten minutes was allowed to pass. The slides were then washed with TRIS again, and after introducing streptavidin peroxidase solution, they were kept in room temperature for ten minutes and then washed with TRIS again. For chromogenic reaction, 3.3-diaminobenzidin (DAB) which had been separately prepared for this purpose was added and 5 minuted was allowed to pass before washing with tap water. Contrast staining was carried out with Mayer hematoxylin, and the slides were washed in water for 1-2 minutes. They were then passed through the rising alcohol stages, rendered transparent with xylol, and covered with lamels.

\section{Immunohistochemical evaluation}

CD23 immune staining score: Brown cytoplasmic or membranous staining for CD23 in germinal centers within the follicular was accepted as positive staining. (Figure 1-4) Stain density and distribution was scored semiquantitively between $0-3$. [0 = no staining (group A); $1+=$ weak staining (group B); $2+$ medium staining (group $C$ ), $3+$ strong staining (group D), diffuse staining of the $90 \%$ or more of the folliculers]. ${ }^{10}$

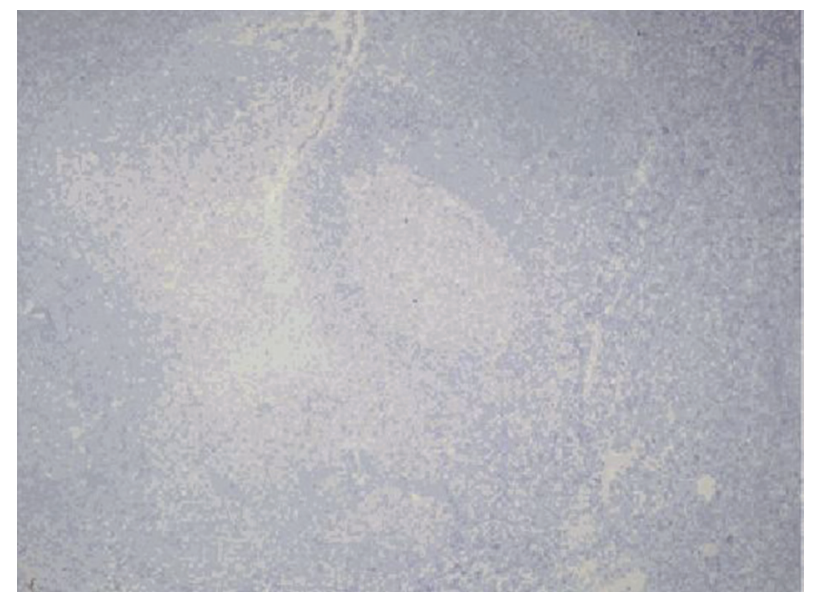

Figure 1. Figure showing that no $C D 23$ staining took place in the adenoid tissue CD23 X 10 folliculars (Score 0)

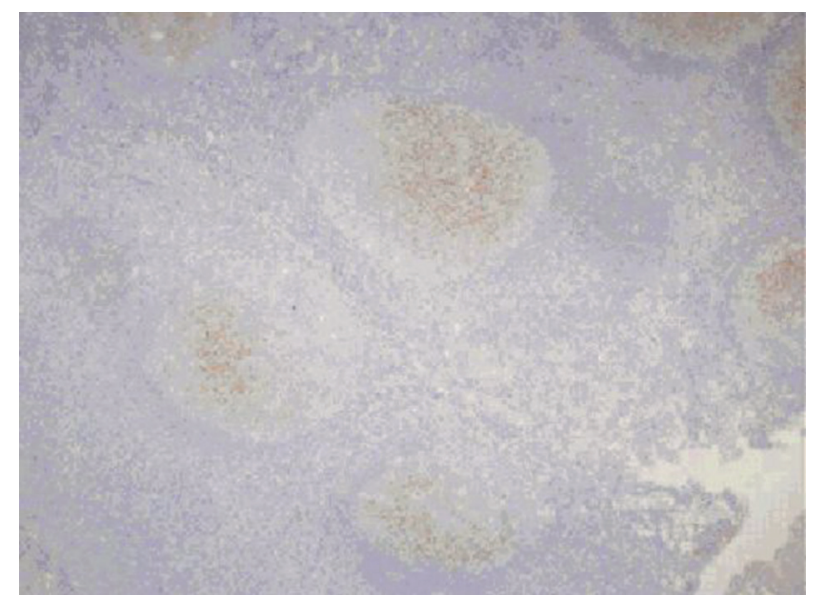

Figure 2. CD23 staining in brown colour in the adenoid tissue CD23 X 10 folliculars (picture related to Score 2) 


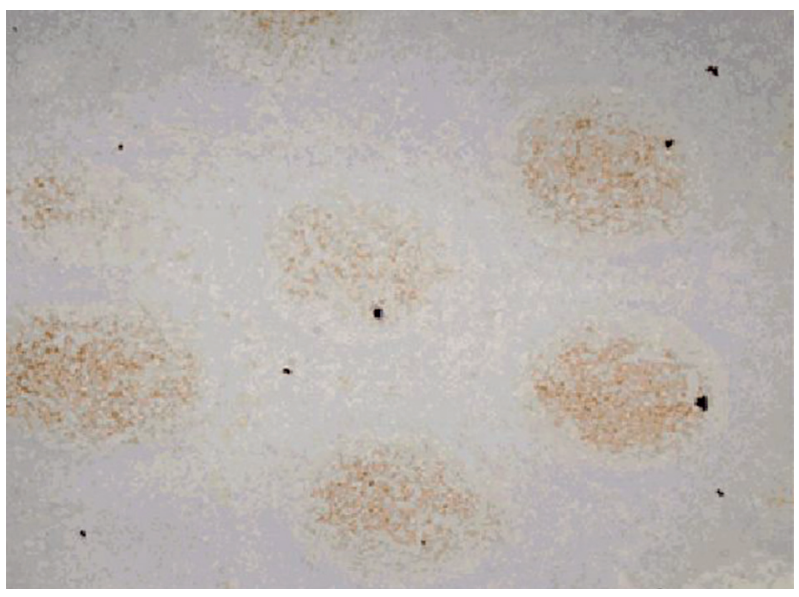

Figure 3. Dense staining in the adenoid tissue CD23 X 10 folliculars (Score 3)

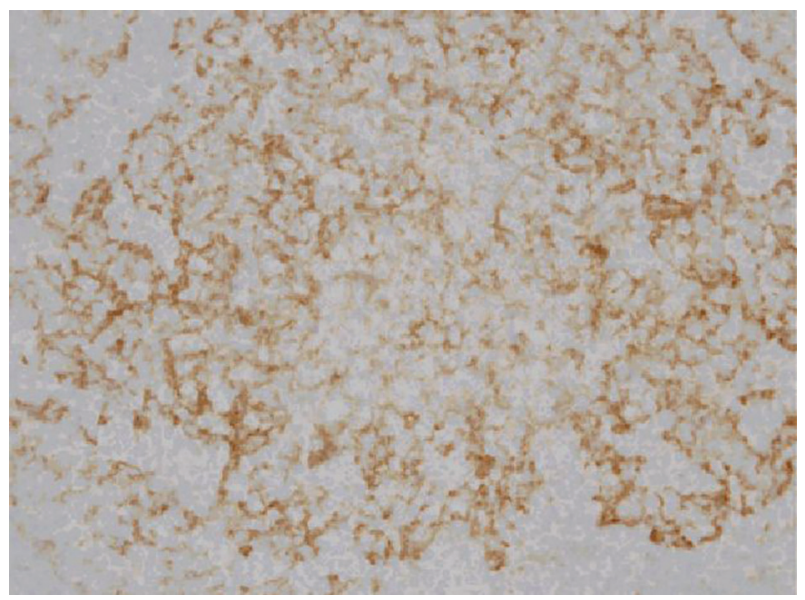

Figure 4. View of Picture-3 (magnified 40 times)

\section{Statistical analysis}

Immune scoring and histopathological evaluation was made by a researcher to whom no clinical or pathological information was disclosed concerning the patients. Data were analyzed with SPSS version 15.0 and chi-square and Fisher exact tests were employed. A value of $<0.05$ was accepted statistically significant.

\section{RESULTS}

Of the study group, $46 \%$ were female. Mean age at surgery was 70.7 months; mean birth weight $3212,8 \mathrm{gr}$; mean gestational week 38.9 weeks. 12 of the patients in the study group had a diagnosis of systemic illness: 3 patients had asthma, 2 patients had congenital heart disease (AVSD and VSD), and each of the remaining 7 patients with a systemic disease had respectively Down syndrome, epilepsy,
MMR, Kawasaki disease, gastroesophageal reflux disease (GERD), vesico-ureteral reflux disease (VUR), and acute disseminated encephalomyelopathy (ADEM). $77 \%$ of the patients had attended a day care center like a nursery or a kindergarten. $57 \%$ had been breastfed for six months or more (Table 1)

Table 1. Descriptive characteristics of the study group

\begin{tabular}{lll}
\hline Parameter & $\begin{array}{l}\text { Number } \\
(\mathrm{n}=100)\end{array}$ & $\%$ \\
\hline Gender & & \\
$\quad$ Female & 46 & 46 \\
$\quad$ Male & 54 & 54 \\
Systemic disease & & \\
$\quad$ Yes & 12 & 12 \\
$\quad$ No & 88 & 88 \\
Attendance to Nursery/Kindergarten & & \\
$\quad$ Yes & 77 & 77 \\
$\quad$ No & 23 & 23 \\
Breast feeding & & \\
$\quad>6$ months & 57 & 57 \\
$\quad<6$ months & 43 & 43 \\
\hline
\end{tabular}

Forty one per cent of the mothers and $59 \%$ of the fathers were smokers. Prevalence of allergic diseases among the parents of the study group was as follows: allergic rhinitis $17 \%$ in mothers and $6 \%$ in fathers; urticaria $8 \%$ for mothers and $4 \%$ for fathers; eczema $3 \%$ for mothers and $4 \%$ for fathers; and asthma $3 \%$ for mothers and $4 \%$ for fathers.

When the results relating to operation specifics are evaluated, $30 \%$ of the patients were treated by adenoidectomy only. 12 patients were administered A ventilation tube was placed during 12 of these surgical procedures. From the viewpoint of post-operational infection frequency and change in allergic symptoms, while infection frequency decreased by $91 \%$, for allergic symptoms decline rate was $11 \%$, with $84 \%$ showing no change and $5 \%$ showing an increase. It was compared patients characteristics and CD23 expression and it was not found any statistically significantly (Table 2 ) .In the study group, 23 cases had urticaria, 15 had pollen allergy, 14 had drugs, 9 had nose drip allergy, 7 had eczema, 4 had food allergy, 2 had allergy to animal hair, and 1 child had angioedema. In the pre-surgery period, the following conditions had been diagnosed in the children, all in repeated form: tonsillitis in $79 \%$, otitis in $29 \%$, sinusitis in $14 \%$, bronchiolitis in $10 \%$, pneumonia in $8 \%$, and croup in $4 \%$. Statistically significantly lower levels of CD23 expression was found in the presence of urticaria $(p=0.041)$, drugs allergy $(p=0.035)$ and pollen allergy $(p=0.037)($ Table 3$)$. 
Table 2. Affected factors of CD23 expression

\begin{tabular}{|c|c|c|c|}
\hline \multirow[t]{2}{*}{ Parameters } & \multicolumn{2}{|c|}{ CD23 expression (\%) } & \multirow[t]{2}{*}{$\mathrm{p}$} \\
\hline & Weak & Profound & \\
\hline \multicolumn{4}{|l|}{ Gender } \\
\hline Female & 82,6 & 17,4 & 0,433 \\
\hline Boy & 74,1 & 25,9 & \\
\hline \multicolumn{4}{|l|}{ Systemic disease } \\
\hline Yes $(n=12)$ & 83,3 & 16,7 & 1,000 \\
\hline No $(n=88)$ & 77,3 & 22,7 & \\
\hline \multicolumn{4}{|c|}{ Attendance to Nursery/ Kindergarten } \\
\hline Yes $(n=77)$ & 79,2 & 20,8 & \\
\hline No $(n=23)$ & 73,9 & 26,1 & 0,801 \\
\hline \multicolumn{4}{|l|}{ Breast feeding } \\
\hline$>6$ months $(n=57)$ & 87,5 & 12,5 & 0,681 \\
\hline$<6$ months $(n=43)$ & 77,2 & 22,8 & \\
\hline
\end{tabular}

Table 3. The relationship between CD23 expression and the allergic diseases

\begin{tabular}{|c|c|c|c|}
\hline \multirow[b]{2}{*}{ Allergic disease } & \multicolumn{2}{|c|}{ CD23 expression (\%) } & \multirow[t]{2}{*}{$p^{*}$} \\
\hline & Weak & Profound & \\
\hline \multicolumn{4}{|l|}{ Eczema } \\
\hline$(+) n=7$ & 100,0 & & \\
\hline$(-) n=93$ & 76,3 & 23,7 & 0,342 \\
\hline \multicolumn{4}{|l|}{ Food allergy } \\
\hline$(+) n=4$ & 100,0 & & \\
\hline$(-) n=96$ & 77,1 & 22,9 & 0,573 \\
\hline \multicolumn{4}{|l|}{ Urticaria } \\
\hline$(+) n=23$ & 95,7 & 4,3 & \\
\hline$(-) n=77$ & 72,2 & 27,3 & $0,041 \bar{\top}$ \\
\hline \multicolumn{4}{|l|}{ Drug allergy } \\
\hline$(+) n=14$ & 100,0 & & \\
\hline$(-) n=86$ & 74,4 & 25,6 & $0,035 \bar{\top}$ \\
\hline \multicolumn{4}{|l|}{ Angioedema } \\
\hline$(+) n=1$ & 100,0 & & \\
\hline$(-) n=99$ & 77,8 & 22,2 & 0,542 \\
\hline \multicolumn{4}{|l|}{ Pollen allergy } \\
\hline$(+) n=15$ & 100,0 & & \\
\hline$(-) n=85$ & 74,1 & 25,9 & 0,037̄ \\
\hline \multicolumn{4}{|l|}{ Mite allergy } \\
\hline$(+) n=9$ & 88,9 & 11,1 & \\
\hline$(-) n=91$ & 76,9 & 23,1 & 0,679 \\
\hline \multicolumn{4}{|c|}{ Animals pile allergy } \\
\hline$(+) n=2$ & 100,0 & & \\
\hline$(-) n=98$ & 77,6 & 22,4 & 1,000 \\
\hline
\end{tabular}

${ }^{*}$ Chi-square test, TFisher's exact test

\section{DISCUSSION}

Upper respiratory tract infections associated with microorganisms and upper respiratory tract symptoms associated with allergic causes overlap. There are quite a number of studies supporting this theory. In a study on 134 children, aged 4 to 8 , with adenoid hypertrophy, Modrzyński et al. encountered obstructive complaints like nasal congestion and snoring in 102 children, recurrent upper respiratory tract infection in 61 children, recurrent otitis in 51 children with accompanying hearing problems in 40 of them. Skin prick tests showed that $30.6 \%$ of the cases were positive for pollen and drips so as to show atopy; however, serum total IgE and peripheral eosinophilia were determined as $17,5 \%$ and $8,5 \%$ respectively, and it was pointed out that adenoid hypertrophy may be an early symptom of atopy. ${ }^{11}$ Becker S. et al. applied an intra-operational multiallergen skin test to 35 infants with recurrent middle ear effusion enlisted for adenoidectomy and found a positive skin test especially for several different pollens and household dust. ${ }^{13}$ Juntti et al. studied the recurrent $A O M$ incidence in children who had cow's milk allergy in infancy with or without accompanying respiratory tract allergy (allergic rhinitis, asthma). It was observed recurrent AOM incidence was higher in children with cow's milk allergy when concurrent respiratory tract allergy was present in comparison with those who had cow's milk allergy alone. ${ }^{18}$ All these researches point to the importance of the intertwined symptoms due to recurrent respiratory tract infections and allergies. This has been the starting point for the present study. The questionnaire was prepared in keeping with internationally used parameters such as "International Study of Asthma and Allergies in Childhood" (ISAAC II) and "The score for allergic rhinitis" (SFAR) ${ }^{19}$ in establishing the clinical parameters.

Histological and immunohistochemical studies have always attracted researchers' attention due to the fact that adenoidectomy and tonsillectomy operations are frequent in childhood period. Dost et al, in their histological study on adenoid and tonsillary tissues comprising the years 1999 to 2004, evaluated 400 children who were 10 years old or under with median age 4 . Of these children, 140 had been treated with adenoidectomy and tonsillectomy together, 26 with tonsillectomy only, and 234 with adenoidectomy only. Histologically, other than lymphoid hyperplasia, chronic tonsillitis and/or adenoiditis, no additional findings were encountered. However, general histological outlook has yielded no information from the viewpoint of immunological responses..$^{20}$ In this study $30 \%$ of the cases had 
been treated with adenoidectomy and $70 \%$ had had adenoidectomy and tonsillectomy together. When the pathology reports pertaining to a total of 168 patients were evaluated, it was likewise seen that histopathological diagnosis was associated with lymphoid hyperplasia and chronic inflammation. On the other hand, 2 patients had actinomyces, and 1 patient had a diagnosis of tuberculous tissue. There are few studies relating to cell surface immunoglobin receptors in adenoidectomy or tonsillectomy tissue. It is possible to come across reports on research pertaining to immunological responses associated with the IgG receptor FcyR expression, which concerns the $\lg$ subgroups especially in repeated infections and allergic ailments. ${ }^{21,22}$ However, we have aimed at demonstrating the presence of CD23 which is known as an IgE receptor. It is remarkable that CD23 has a greater immunomodulatory effect as a differentiating factor from the other Fc receptors and that it plays a greater role in natural mucosal immunity thanks to its lectin characteristic as having a protein structure which binds mannose. Due to a scarcity of tissue studies related to CD23, there are many points which have not been elucidated. Apart from binding IgE, CD23 also has the ability to bind CD21, CD11b ve CD11c. This explains its versatility in Immune functions. ${ }^{24}$ Its expression is a dynamic event and is dependent on the balance between synthesis and proteolysis. The event is affected by the concentration and profile of the cytokines that are engendered. In atopic patients, there may be seen differences in both receptor expression and in the forming of $\lg$ E synthesis..$^{25}$ In the present study, it was established, in a similar way as in other studies, that CD23 expression shows a significant decrease in patients with urticaria, drugs allergy and pollen allergy. It is shown that IgE binding to CD23 regulates IgE formation by negative feedback mechanism. ${ }^{24}$ Although there is some data suggesting that CD23 surface expression and soluble CD23 release will be higher in atopic patients in comparison with non-atopic ones, there are also results that demonstrate exactly the opposite. Higher level sCD23 and surface expression have been determined in peripheral blood mononuclear cells in individuals with silver birch allergy when they are compared with non-atopic patients. ${ }^{24}$ Again, CD23 expression on the surface of peripheral blood $B$ lymphocytes have been shown to decrease one week following immunotherapy. ${ }^{24}$ In both events, the synthesis of CD23 cell surface receptor is lowered following the signals that IgE bound CD23 conducts into the cells through negative feedback. The present study has focused on the argument that mucosal tissue cell surface expression, rather than that in the peripher- al blood, may reflect the immunological responses more efficiently from the viewpoint of cell surface expression.

The most restricting factor in this study, however, was the fact that it is a retrospective study. It is an expected situation that immune functions of the patients change with advancing age. It is for this reason that patients have been evaluated especially in such a wide spectrum of age. The aim thus was to have a patient population more homogeneous and over a longer period in which to study their immune functions, lymphoid tissue development and contact with allergens. The foremost disadvantage of the study was the fact that the patients were retrospectively evaluated on the basis of their history, with their later impressions lacking in the picture. Notwithstanding, these results may suggest the way for future prospective studies that a sounder correlation between the density of CD23 expression and clinical evaluation should be aimed at to help shape a more practical assessment and treatment for these patients.

\section{REFERENCES}

1. Lack G, MD Pediatric Allergic Rhinitis and comorbid disorders. J Allergy Clin Immunol 2001;12:9-15.

2. Bluestone CD.Eustachian tube function: physiology, pathophysiology, and role of allergy in pathogenesis of otitis media. J Allergy Clin Immunol 1983;72:242245.1

3. Shapiro GG. Role of allergy in sinusitis. Pediatr Infect Dis J 1985;4:55-59.

4. Bluestone CD. Eustachian tube function: Physiology, pathophysiology, and role of allergy in pathogenesis of otitis media. J Allergy Clin Immunol 1983;72:242251.

5. Siegel G. Theoretical and clinical aspects of the tonsillar function. Int J Pediatr Otorhinolaryngol 1983;6:6166.

6. Capron A, Dessaint JP, Capron M, et al. From parasites to allergy: a second receptor for IgE. Immunol Today 1986;7:15-20.

7. Aubry JP, Pochon S, Graber P, et al. Nature 1992;358:505-507.

8. Liu YJ, Cairns JA, Holder MJ, et al. Recombinant 25kDa CD23 and interleukin 1 alpha promote the survival of germinal center B cells: evidence for bifurcation in the development of centrocytes rescued from apoptosis. Eur J Immunol 1991;21:1107-1114.

9. Hertl M, Asada H, Katz SI. Murine epidermal Langerhans cells do not express the low-affinity receptor for immunoglobulin E, FcEpsilonRII (CD23). J Invest Dermatol 1996;106:221-224.

10. Maesano AI, Didier A, Klossek M, et al. The score for allergic rhinitis (SFAR): a simple and valid assessment 
method in population studies Allergy 2002;57:10071014.

11. Modrzynski M, Zawisza E, Rapiejko P, et al. The occurrence of atopic hypersensitivity in children with adenoid hypertrophy Przegl Lek 2002; 59:1003-1006.

12. Huang SW, Giannoni C. The risk of adenoid hypertrophy in children with allergic rhinitis. Ann Allergy Asthma Immunol 2001;87:350-355.

13. Becker S, Koch T, Philipp A. Allergic origin of recurrent middle ear effusion and adenoids in young children. HNO 1991;39:182-4.

14. Tomonaga K, Krono Y, Mogig. The role of nasal allergy in otitis media with effusion: a clinical study. Acta Otolaringol Suppl 1988;458:41-47.

15. Doner F, Yarıktas M, Demirci M. The role of allergy in recurrent otitis media with effusion. Otolaringol Head Neck Surg 2004;130: 95-118.

16. Nguyen LHP, Manoukian JJ, Tewfik TL, et al. Evidence of Allergic Inflammation in the middle ears of children with otitis media with effusion. Laryngoscope1999;109:471-477.

17. Hurst DS, Amin K, Seveus L, et al. Evidence of mast cell activity in the middle ears of children with otitis media with effusion. Laryngoscope 1999;109:471477.

18. Juntti IJ, Tikkanen S, Kokkonen J, et al. Cow's milk allergy is associated with recurrent otitis media during childhood. Acta Otolaringol 1999;119:867-873.
19. Yenigün A. Çocukluk Çağında allerjik rinit, allerjik rinitte klinik ve laboratuar bulguları, tanı ve ayırıcı tanı. Güncel Pediatri Dergisi, 2007;1:26-231.

20. Dost P. Histological examination following adenoidectomy and tonsillectomy in children. Surprising results are very rare. HNO 2006;54:16-19.

21. Sekerel BE, Saraclar Y, Sanal O, et al. IgG subclasses in children with recurrent respiratory tract infections in an allergy practice. Acta Paediatr Jpn 1996;38:124127.

22. Tuijnman WB, Van Wichen DF, Schuurman HJ. Tissue distribution of human IgG Fc receptors CD16, CD32 and CD64: an immunohistochemical study. APMIS 1993101:319-329.

23. Özbaş-Gerçeker F. Tezcan I, Berkel Al. The effect of mannose-binding protein gene polymorphisms in recurrent respiratory system infections in children and lung tuberculosis. Turk J Pediatr 2003;45:95-98.

24. Roever AC, Heine G, Zuberbier T, et al. Allergen-mediated modulation of CD23 expression is interferonand interleukin-10 dependent in allergic and nonallergic individuals Clin Exp Allergy 2003;33:1568-1575.

25. Corominos M, Mestre M, Bos J. Distinct modulation by interferon-gamma(IFN- $\gamma$ ) of CD23 expression on B and T lymphocytes of atopic subjects. Clin Exp Immunol 1998;112;276-280. 